\title{
Factors Affecting the Success in Certified Public Accountant Exam in Kuwait
}

\author{
Nabi Al-Duwaila ${ }^{1}$ \& Abdullah AL-Mutairi ${ }^{2}$ \\ ${ }^{1}$ Public Authority for Applied Education and Training (PAAET), Kuwait \\ ${ }^{2}$ Gulf University for Science and Technology, Kuwait \\ Correspondence: Abdullah AL-Mutairi. E-mail: mutairi.a@gust.edu.kw
}

Received: September 21, 2020

Accepted: December 11, 2020

Online Published: December 30, 2020

doi:10.5539/ass.v17n1p98

URL: https://doi.org/10.5539/ass.v17n1p98

\begin{abstract}
The aim of the article is to assess the variables that are influenced performance on the Certified Public Accountant (CPA) exam in Kuwait. To achieve the aim of the study, structure questionnaire was improved and delivered to a sample of (150) of the study population of candidates recently licensed CPAs to find out their interpretations of the causes that influence their performance on the CPA exam, the amount of questionnaires returned and ready for analysis was (120),with a reply rate of $80 \%$.

The study showed that the success of the CPA exam in Kuwait is generally dependent on factors related to the exam itself and the candidate who is taking the exam. It reported that the most important challenges linked to the CPA exam are unlimited scope of the CPA exam followed by the exam's questions do not cover all subjects and the exam does not measure the examinee's capabilities. Moreover, the analysis showed that insufficient preparation of the exam is the main variable affecting the performance of CPA exam followed by accepting the idea of repeating the exam. Finally, the study recommends that academicians in accounting should train the students for the exam. They should pay attention to curriculum to assure that learners are provided the good training for the examination.
\end{abstract}

Keywords: accounting education, CPA exam, passing rates, success factors, academic performance, professional accounting career, Kuwait

\section{Introduction}

Accounting as a measuring and communicating vehicle plays a major role in economic planning, control and decision making. Accountants attempt to develop their skills by passing Certified Public Accountant (CPA) exam which become a dream for each accountant. Passing the CPA exam represents a main milestone on the path to obtaining the CPA designation. It serves as a benchmark to verify that a candidate for certification has succeeded an advanced level of accounting knowledge.

Empirical studies for the factors leading to success in CPA exam have raised several issues such as the candidate's Grade Point Average (GPA) (Dunn \& Hall, 1984), the credit hours in general education (Suluom \& Masoud, 2014); accounting schools with Association to Advance Collegiate Schools of Business (AACSB) accreditation (Hahn \& Fairchild, 2015), the time available to the candidate (Cardona et al., 2015) and the type of CPA training program (Morgan, 2015). These findings, however, seem to be questionable for the accounting graduates in Kuwait.

The aim of this study is to investigate the factors behind influencing the performance of candidates on the CPA exam in Kuwait. Understanding the variables behind passing CPA exam is of interest for both applicants and educational institutions. For the former, it is considered a prestigious achievement for applicants to pass all four parts of the exam with high scores. For the latter, it might reflect the quality of educations for the educational institutions which reported high level of success rate of their graduates. Moreover, it might provide further information to develop the academic environment in Kuwait by raising those factors that guide to applicant's success on the CPA exam.

This article is organized into four sections. The next part furnishes quick review of existing literature and prior studies. The third part offers data collection and research method. The outcomes and analysis are presented in part four. Conclusion and recommendations are showed in the last part. 


\section{Related Literature and Previous Studies}

To be a Certified Public Accountant (CPA) is a desire for any graduate with a Bachelor's Degree in Accountancy. CPA is multi-talented professionals and is viewed as an influential group of professionals (Tan, 2014). Moreover, CPA is appreciated and admired by their peers, clients and society and adds prestige and respect. However, the variables that might influence performance of the accountant to be CPA can be divided into two main categories namely variables related to the candidate and variables related to the exam. According to Reilly and Stettler (1972) the candidates' grade point in college courses is the most significant explanatory variable that affects success on the CPA examination. Trinkle et al. (2016) demonstrated that young male candidates who obtained their degree from business college which is private and member in AACSB is likely to pass the exam more than other candidates.

Numerous researches have been performed to find out the factors leading to CPA examination success in various countries (see for example, USA: Dunn \& Hall, 1984; Titard \& Russell, 1989; Shbaugh \& Thompson, 1993; Campbell, Lindsay, \& Foote, 2000; Brahmasrene \& Whitten, 2001; Whitten \& Brahmassrene, 2002; Howell \& Belk, 2003. Cocozza, 2005; Howell \& Heshizer, 2006; Boone, Legoria, Seifert, \& Stammerjohn, 2006; Charron \& Lowe, 2009; Lindsay et al., 2009; Metinko \& Gray, 2010; Lindquist \& Smith, 2013; Lightweis, 2014; Hahn \& Fairchild, 2015; Morgan, 2015; Hahn \& Fairchild, 2015; Trinkle et al., 2016; Nigeria: Odia \& Ogiedu, 2013. Jordan: Momany, 2013; Abd-Al-Jaleel \& Thaher, 2015. Tanzania: Masasi, 2012; Suluom \& Masoud, 2014. Japan: Sugahara, Hiramatsu, \& Boland, 2009; Sugahara \& Boland, 2014. Philippine: Perez, 2013; Tan, 2014; Tan, 2015; Jalagat, 2016. Puerto Rico: Cardona et al., 2015. Malaysia: Samsuri et al., 2016). The next portion reviews in short of these researches.

Dunn and Hall (1984) examined the association between the features of CPA examination candidate and his or her performance in the CPA exam. They found that the candidate GPA in accounting, accounting hours completed and completion of a CPA review course have significant relationship with the candidate's performance in the exam. Titard and Russell (1989) found that there is a positive relationship between the success of candidate on all parts of the CPA exam and the candidate's GPA. Another study conducted by Shbaugh and Thompson (1993) who added that the main variables to pass the CPA exam are CPA review course grade, high school class rank and the class size.

Campbell et al. (2000) noticed that there is a statistically significant association between the requisite of a governmental/not-for-profit accounting course in the program and the CPA exam. The researchers concluded that the presence of such coursework is likely to enhance the performance of the candidate in the exam.

In addition, Brahmasrene and Whitten (2001) examined the variables leading to pass the CPA exam. They found that the performance of the males seems to be more successful than the performance of females in passing the exam. They researchers also demonstrated that having experience in private sector is likely to facilitate reaching a successful result in the exam. In other study, Whitten and Brahmassrene (2002) provided evidence that the performance of females in the exam is the same as the performance of males on the first sitting, but do not do the same in following sittings.

Howell and Belk (2003) identified the reasons behind the CPA exam's passing rate much lower than the Bar exam's passing rate. They found that the perception of the CPA exam as being more difficult than the Bar exam. They observed that the difference in passing rates can be explained by differences in admission standards. They provided evidence that the breadth of knowledge tested is one of the main obstacles for both exams.

Cocozza (2005) studied the variables affecting the outcome of the CPA exam. The author encouraged that the candidates should take the exam once they complete the requirements. Howell and Heshizer (2006) examined the role of AACSB accreditation for passing CPA exam. The researcher found that AACSB accreditation grade has a significant impact in decreasing the number of tries to exceed the CPA exam. They concluded that learning for the exam with self-study is likely to raise the number of tries wanted to exceed the exam. Boone et al. (2006) examined the relationship among accounting program attributes, 150-hour status, and CPA exam pass rates. The researchers found that there is a weak relationship between program-level pass rates and college-level or separate AACSB accounting program accreditation.

Another study conducted by Charron and Lowe (2009) who examined the attitudes of candidate towards CPA exam. They found that candidates prefer to take a computerized exam. Lindsay et al. (2009) examined the relationship between the design of undergraduate accounting programs and the passing rates of the CPA exam. They found that the cost and managerial accounting semester hours play important factors of passing the new part of the CPA exam. Metinko and Gray (2010) examined the relationship between the 120/150-hour education requirement and the number of CPA exam candidates from the period 1998 till 2008. They concluded that there 
is no relationship between 150-hour requirement and the number of people taking the CPA exam. Lindquist and Smith (2013) investigated the program quality to assess what business school is doing different from other schools. They used AACSB is an indicator of program quality. They also demonstrated that the success on CPA exam needs hard working students.

Lightweis (2014) recommended that accounting professors should apply their experience as an accounting practitioners and construct simulations that portray the challenges in the field. Hahn and Fairchild (2015) provided evidence that schools with AACSB accreditation achieved statistically significantly higher pass rates when compared to each of these groups. Morgan (2015) revealed a positive association between program selectivity and CPA exam pass rates. Also, Hahn and Fairchild (2015) examined the quality purpose at U.S. institutions of higher education. They found that schools with the AACSB accreditation achieved statistically significantly higher pass rates when compared to each of these groups. They also found that there is a positive relationship between passing the exam with small class sizes as well as effective education approaches used in the classroom.

Additionally, Trinkle et al. (2016) examined the relationship between individual, institutional, and jurisdictional factors and the probability of passing the Uniform Certified Public Accountant Examination. They found that candidates seem to pass on the CPA exam if they are young male obtained a degree from private college with an AACSB accredited business school AACSB accredited accounting program.

In Nigeria, Odia and Ogiedu (2013) investigated the elements behind influencing students' career choice of accounting in Nigerian universities. They revealed that the most important variables are personal and job issues such as students' interest and incentive in the subject, job prospects and high salary. They also observed that male students are more motivated by the reference factors than their female counterparts in the choice of accounting.

In Jordan, Momany (2013) examined the variables behind passing the Jordanian Certified Public Accountants (JCPA) exam. He found that the type of university and area of students' specialization are important factors that enhance the probability of passing the unified JCPA exam. In contrast, Abd-Al-Jaleel and Thaher (2015) do not find any evidence for the impact of academic qualification, experience, gender, or type of universities the students are graduated from.

Masasi (2012) studied the relationship between the personal attributes and the students' performance in undergraduate accounting course. He found that there is a negative relationship between students staying with relatives and his academic performance. Suluom and Masoud (2014) examined the relationship between various attributes of candidates' undergraduate academic achievement and candidates' performance in the CPA examination. They found that there is a positive, statistically significant correlation between the examination scores and the candidate's grade point average (GPA) and credit hours in general education.

Sugahara et al. (2009) examined the factors affecting career plans to become a CPA by students who are studying accounting in Japan. They found that students with work experience and major in disciplines other than accounting are more unwilling to become a CPA. Another study conducted by Sugahara and Boland (2014) who used questionnaire to explain the meaning of success for the students who are studying accounting at Accounting Schools (ASs) in Japan. They found that the majority of students attended the ASs for individual progress rather than passing CPA/Tax Accountants (TA) exam. The researchers recommended that accounting academicians at the ASs need to develop the curriculum by adding unstructured and problem-based learning materials.

Perez (2013) attempted to determine the performance of Lyceum of the Philippines - Laguna Bachelor of Science in Accountancy students in the past CPA Licensure Examination covering the period from October 2006 to October 2013. He found that 46 percent of the total graduates became licensed certified public accountants. $\mathrm{He}$ also found that it takes a maximum of five times before a candidate become a licensed certified public accountant. Another study conducted by Tan (2014) who examined the association between the attitudes of students towards their performance in licensure examination of accountancy graduates. He found that the positive attitude towards accounting paired with efficient learning practices lead to superior academic performance and then better probability of succeeding the board exam.

Likewise, Tan (2015) examined elements behind increasing the performance of the candidate in the CPA licensure examination. He found that there is a positive relationship between the participants' performance in the examination and instruction and administrative support. He stated that it is important to revise the current curriculum to match the mandated curriculum by the Commission on Higher Education as an attempt to remove unnecessary subjects. 
Furthermore, Jalagat (2016) attempted to determine the of accounting graduates' performance in CPA board examination of the three selected schools in Cagayan de Oro City, Philippines for the school year 2003-2009. The researcher found that the performance in school may not solely be determinant to passing the board examination. He observed that there is positive significant relationship between graduates' performance in Math, English and Professional Accounting subjects and the performance in CPA examination. He concluded that schools should consider the performance of the students in the Math, English into the admission of the Accountancy program.

Cardona et al. (2015) analyzed the variables behind affecting the participant's performance in CPA exam. They distributed that candidates who passed the four sections of the CPA exam into three parts. The first part which includes approximately 42 percent described themselves as working part time. The second part which covers approximately 54 percent are working full time while the third part which covers 4 percent is unemployed. They concluded that the participants strongly do not have enough time to study.

Samsuri et al. (2016) examined the attitudes of students in accounting to professional accounting in Malaysia. They found that most of the students think that professional accountant is greatly required in job market. They also found students' parents and family members have major influence on students to study professional accountant.

In the GCC region, few studies have been conducted to identify the factors leading to success in accounting exam in various countries (see for example, Saudi Arabia: Atieh, 1997. United Arab Emirates: Harb \& El-shaarawi, 2007. Kingdom of Bahrain: Kukreja \& Al Aali, 2013. Kuwait: Almunais et al., 2014). The following section submits a short review of the above researches.

Atieh (1997) attempted to assess the reasons behind low performance of the students in principles of accounting. He reported that the belief of the students that accounting is hard course considers the main problem. Harb and El-shaarawi (2007) examined the main cause that shaped student performance in United Arab Emirates. They found that participants who involves in class discussions and leave from their jobs are doing better than other participants. Also, they reported that nonnational students are performing better than national students, and female students are making better than male counterparts. Kukreja, and Al Aali (2013) attempted to assess the variables behind influencing the performance of the students in first two introductory accounting courses at undergraduate level of Ahlia University. They provided evidence that student's GPA is playing significant role to determine the performance in ACCT 101.

In Kuwait, Almunais et al. (2014) examined the factors affecting the performance of students in accounting the College of Business Studies at the Public Authority for Applied Education and Training in Kuwait. They found that there is statistically significant relationship between the performance of the student and the gender, high school major, age, frequency of doing homework. They also observed that participation in class discussion and engaging in peer interaction play significant positive role in student's performance. Almunais et al.; provided evidence that number of days studying before exam are positively related to students' performance in accounting.

It is evident that a limited number of empirical studies have been undertaken on to assess the factors behind leading to CPA examination success in GCC region. This implies the need for extra empirical analysis. Hence, this study is started to test following hypotheses:

Hypothesis 1 : There is a relationship between the pass rate in the CPA exam and the scope of the exam.

Hypothesis 2 : There is a relationship between the pass rate in the CPA exam and the exam's questions.

Hypothesis 3 : There is a relationship between the pass rate in the CPA exam and the examinee's capabilities.

Hypothesis 4 : There is a relationship between the pass rate in the CPA exam and the preparation time.

\section{Study Methodology}

\subsection{Research Instrument}

The aim of this article is to explain the variables that might help to pass the CPA exam in Kuwait. The study used questionnaire which was distributed among participants who took CPA exam and recently licensed CPAs to report their attitudes to the items that enhance their performance on the CPA exam. Candidates were requested to complete a questionnaire that contained two parts. Part one comprises common data about the participant such as age, GPA at graduation, major and years of public accounting experience. Part two contains some factors that might lead to the success in CPA exam in Kuwait. The choice of the factors included in the survey was based on the grounds that they have been heavily documented in previous research such as Momany (2013) in Jordan, 
Sugahara and Boland (2014) in Japan, Tan (2014) in Philippine, Cardona et al. (2015) in Puerto Rico and Morgan (2015) in USA.

The researchers used previous empirical studies to develop the structure of the questionnaire to achieve the study's objectives. The questionnaire was revised by experts in the same field in different educational institutions as an attempt to attain the great rank of validity and adjusted according to their propositions and advices. Consequently, new questions were included and other questions were revised. The revised questionnaire comprised 5- point Likert scale items. It is worth mentioning that the questionnaire lets the participant to assess each of the element item on a five-point scale covering from strongly disagree (1) to strongly agree (5) where (3) stood for a neutral response.

During the period between November 2018 and April 2019, a modified questionnaire was distributed among 150 participants taking CPA exam. 120 questionnaires were returned; ensuing $80 \%$ valid reply rate.

After that the collected data was inserted in Statistical Package for Social Sciences (SPSS) file for investigation. In order to test the internal consistency of the collected data, the researchers checked Cronbach's Alpha which indicated 0.82, suggesting high internal consistency of the items. It is worth to be mentioned that a Cronbach's Alpha $(\alpha)$ should be more than 0.70 . Then, the study employed descriptive statistics as an attempt to identify the factors that are influenced performance on the CPA exam. Furthermore, the study used regression analysis to recognize the most variables behind affecting the performance of CPA on the exam.

\subsection{Respondents' Background}

Table 1 shows background statistics of the respondents who involved in the study. The majority of the respondents (75 percent) are married and 25 percent of them are not married. Furthermore, about 67 percent of the participants are male while the rest of participants are female. This statistic provides clear evidence that females are not encouraged to be CPA. It is worth to be mentioned that all the participants in the study are Kuwaitis since it is not allowed to non-Kuwaitis to enter the exam and practice auditing ${ }^{1}$.

Table 1. Respondents background

\begin{tabular}{|c|c|c|c|c|c|}
\hline & Frequency & Percent & & Frequency & Percent \\
\hline Gender & & & \multicolumn{3}{|c|}{ Academic Qualification } \\
\hline Male & 80 & 66.7 & Bachelor & 100 & 83.3 \\
\hline \multirow[t]{2}{*}{ Female } & 40 & 33.3 & Masters & 15 & 12.5 \\
\hline & & & $\mathrm{PhD}$ & 5 & 4.2 \\
\hline Total & 120 & 100 & Total & 120 & 100 \\
\hline \multicolumn{3}{|c|}{ Working place } & \multicolumn{3}{|c|}{ Marital Status } \\
\hline Private sector & 30 & 25.5 & Single & 30 & 25.0 \\
\hline Public sector & 80 & 66.7 & Married & 90 & 75.0 \\
\hline \multirow[t]{2}{*}{ Others } & 10 & 8.4 & Total & 120 & 100 \\
\hline & & & \multicolumn{3}{|c|}{ Your School } \\
\hline \multirow[t]{2}{*}{ Total } & 120 & 100 & Member in AASCB & 84 & 70 \\
\hline & & & Not member in AASCB & 36 & 30 \\
\hline Your GPA & & & Total & 120 & 100 \\
\hline Below 2.00 & 10 & 8,33 & \multirow{2}{*}{\multicolumn{3}{|c|}{ Age }} \\
\hline $2,00-2,66$ & 70 & 58,3 & & & \\
\hline $2.67-3.00$ & 20 & 16.7 & Less than 30 years old & 40 & 33.3 \\
\hline $3.01-3.49$ & 10 & 8.33 & From 30 - 40 years old & 38 & 31.7 \\
\hline $3.50-3.74$ & 6 & 5.0 & From $40-50$ years old years & 30 & 25.0 \\
\hline $3.75-4.00$ & 4 & 3.33 & Over 50 years old & 12 & 10.0 \\
\hline $\begin{array}{c}\text { Total } \\
\text { Source: Authors }\end{array}$ & 120 & 100 & Total & 120 & 100 \\
\hline
\end{tabular}

\footnotetext{
${ }^{1}$ Requirements for the audit license in Kuwait

1- Kuwaiti citizenship

2- Bachelor's degree in accounting;

3- having completed at least five (5) years of practical experience in auditing/accounting;

4- having a clear criminal record; and

5-membership in Kuwait Association of Accountants and Auditors.
} 
Table 1 also presents that more than 60 percent of participants' age is below 40 years implying the dominance of the younger generation on the Kuwait economy in chasing CPA exam. It is likely that younger participants have a better chance for success on the CPA exam than older ones. In addition, the majority of the participants (70 percent) have graduated from AACSB accredited business school, while the rest of participants. It is well-known that AACSB is an indicator of quality of accounting program (Morgan et al., 2008). AACSB business schools are likely to provide students with more accounting information and train them for CPA exam to increase their chance to pass the exam. Morgan et al. (2008) demonstrated that student who graduated from AACSB schools has higher pass rates on all sections than student who graduated from unaccredited schools. Thus, it is not surprising that many business programs are keenly pursuing to maintain AACSB accreditation.

Of the 120 participants in the survey, the GPA of 120 participants (67 percent) is less than 2.66. It is worth to be mentioned that GPA is an indication of success and delivers information about the level of candidate coursework mastery. Candidate with better mastery of coursework is anticipated to achieve well in his or her professional examinations. The CPA exam is a textbook exam; so, high GPA is likely to increase the opportunity to pass the CPA exam (Momany, 2013). Moreover, in terms of educational level, it is obvious that the majority of participants have bachelor's degree in accounting, while 12.5 percent and 4.2 percent obtain Master and $\mathrm{PhD}$ degree respectively.

\section{Finding and Analysis}

The first question in the survey asked the participants to furnish their attitudes towards the obstacles' factors behind passing the CPA exam. The participants were requested to rank their degree of agreement about each one of them. The outcome of their answers is summarized in Table 2.

Table 2. Factors related to CPA exam

\begin{tabular}{lccc}
\hline Factor & Mean & SD & Rank \\
\hline The scope of the exam is not identified & 4.3 & .52 & 1 \\
The exam's questions are not clear & 3.0 & .77 & 7 \\
The exam's questions do not cover all subjects & 4.1 & .52 & 2 \\
Changes in accounting standards & 3.7 & .65 & 4 \\
Lack of proper references & 3.6 & .73 & 5 \\
The time allocated for the exam is insufficient & 1.7 & .82 & 9 \\
The exam does not measure the examinee's capabilities & 4.0 & .75 & 3 \\
The distribution of scores between papers is not fair & 2.3 & .82 & 8 \\
Continuous changes in rules and regulations & 3.3 & .55 & 6 \\
The exam environment (exam halls) are not suitable & 1.5 & .84 & 10 \\
\hline
\end{tabular}

It is shown from the table that the participants confirmed that the main obstacles factors behind passing the CPA are the scope of the exam is not identified with mean 4.3 and .82 standard deviation, the exam's questions do not cover all subjects with mean 4.1 and, 52 standard deviation and the exam does not measure the examinee's capabilities with mean 4.0 and .75 standard deviation. The possible interpretation for this outcome is attributed to the fact that student in GCC region prefers determining the scope of the exam as an attempt to manage his or her time to complete and control the whole subject. The findings are on line with the result reached by Abd-Al-Jaleel and Thaher (2015) who reported that the wide scope of the exam is one of the main obstacles factor behind passing the CPA exam to accountants in Jordan. It is also consistent with the result reached by Howell and Heshizer (2006) who reported that breadth of knowledge actually tested on the examinations is the main obstacle for candidate behind passing the CPA. Furthermore, Cardona et al. (2015) demonstrated that level of technical difficulty of the exam is one of the most important challenges associated with passing the CPA. Tan (2015) pointed out that accountancy curriculum should match CPA exam and satisfy the requirements of recruitment and selection. It is worth to be mentioned that Abd-Al-Jaleel and Thaher (2015) do not find any evidence for the impact of academic qualification, experience, gender, or type of universities the respondents were graduated from on passing rate in the CPA exam.

It can also be gleaned on the table that the exam does not measure the examinee's capabilities is one of the obstacles facing candidates to pass CPA exam. The possible explanation for this finding is attributed to the fact that Arabian student prefers to focus on particular material rather than wide area of information. Furthermore, the high-quality accounting programs do not focus only on the public accounting career route for the learner. The outcome is on line with the results reached by Morgan et al. (2008) who argued that the CPA exam is not a comprehensive measure of accounting knowledge or skills. In addition, Howell and Belk (2003) stated that the 
breadth of knowledge tested is one of the main obstacles for CPA exam.

Table 3. Factors related to accountant preparing the exam

\begin{tabular}{|c|c|c|c|}
\hline Factor & Mean & SD & Rank \\
\hline Preparing for the exam is not enough & 4.3 & .53 & 1 \\
\hline Careless towards the exam & 2.5 & .73 & 6 \\
\hline Accepting the idea of repeating the exam & 4.2 & 63 & 2 \\
\hline Limited auditing experience & 3.1 & .71 & 4 \\
\hline Not attending training programs & 4.0 & .66 & 3 \\
\hline Old references & 2.3 & .75 & 7 \\
\hline Exam's fees do not burden the examinee & 3.0 & 63 & 5 \\
\hline
\end{tabular}

The second question in the survey asked the participants to provide their attitudes towards the factors related to accountant preparing the CPA exam. The outcomes of their answers are summarized in Table 3.

It is shown that insufficient preparation time for the exam is the main variable affecting the performance of CPA exam followed by accepting the idea of repeating the exam. CPA exam is professional one which aims to build body of knowledge and foundation covers more topics in accounting. The participants might give little time for preparation of the exam due to the responsibilities of participants towards their families while studying for the exam. So, being a parent rationally has a few obstacles and challenges at times to CPA exam preparation. According to Burton et al. (2014) candidates should spend more time to increase their chance to pass the CPA exam.

Perez (2013) argues that the lack of preparation of the CPA exam seems to be the main influence on the candidate's performance. However, the findings are on line with the result reached by Sugahara and Boland (2014) who stated that reviewing and preparing classes play significant role for student to pass the exam. Also, Abd-Al-Jaleel and Thaher (2015) provided evidence that insufficient preparation for the exam considers one of the main obstacles behind passing the CPA exam to accountants in Jordan. However, Suyder (2004) proposed some tips on preparing employees for CPA exam such as decide whether to take which part in the exam and schedule time off in advance so that you are available and coordinate the schedule with their employers. Whitten and Brahmassrene (2002) added that the available study time is important for candidate to pass CPA exam.

\section{Conclusion}

The purpose of the study is to examine the variables behind affecting the performance on the CPA exam by students. CPA covers four sections includes auditing \& attestation, financial accounting \& reporting, regulation and business environment and concepts. To accomplish this purpose, structure questionnaire was circulated among accountants during the period between November 2018 and April 2019.

The sample consists of participants who have either Bachelor, Master or Ph.D. in Accounting and at least one-year experience working in auditing in Kuwait. In terms of age, $65 \%$ of the respondents are less than 40 years of age. Regarding gender of the respondents, $67 \%$ are male and $33 \%$ are female and the majority (75\%) of the respondents classified themselves as married.

The success of the CPA exam in Kuwait is generally dependent on factors related to the exam itself and the candidate who is taking the exam. According to the study's participants, the important obstacles related to the CPA exam are the scope of the exam is not identified followed by the exam's questions do not cover all subjects and the exam does not measure the examinee's capabilities. The above results are likely to be consistent with previous researches. So, it might be recommended that accounting professional body should publish some material which related directly to CPA exam. Moreover, the exam environment is not observed to be obstacle in succeeding the CPA exam among the participants.

Likewise, the participants in the study revealed that insufficient time preparing for the exam is the main variable affecting the performance of CPA exam followed by accepting the idea of repeating the exam are the main obstacles facing candidates. However, there is a need for the forthcoming students to have a desire for the discipline they are selecting to make them overcome all obstacles that they may face.

The outcomes presented in this research should be viewed in light of particular constraints. It considers only accounting graduates in Kuwait who became CPA, other accounting graduates from GCC countries may have dissimilar opinions about the CPA exam. Therefore, it may be valuable to redo this study in one of the GCC countries. Future research might be included a sample of participants and compare between the factors behind passing CPA exam and other finance professional exam such a Chartered financial Analyst (CFA). 


\section{Acknowledgments}

This work supported and funded by The Public Authority of Education and Training, Research project No (-BS-18-01), Research Title (Factors leading to Success in Certified Public Accountant Exam in Kuwait)

\section{References}

Abd-Al-Jaleel, T., \& Thaher, A. (2015). The obstacles of success of Jordanian certified public accountant. Dirasat: Administrative Sciences, 42(1), 203-218. https://doi.org/10.12816/0016596

Almunais, T., Alfraih, M., \& Alharbi, F. (2014). Determinants of accounting students performance. Business Education \& Accreditation, 6(2), 1-9.

Atieh, S. (1997). Student perceptions of the causes of low performance in principles of accounting: A case study in Saudi Arabia. JKAU: Econ. \& Adm., 10, 35-50. https://doi.org/10.4197/Eco.10-1.2

Boone, J., Legoria, J., Seifert, D., \& Stammerjohn, W. (2006). The association among accounting program attributes, 150-hour status, and CPA exam pass rates. Journal of Accounting Education, 24(4), 202-215. https://doi.org/10.1016/j.jaccedu.2006.08.002

Brahmasrene, T., \& Whitten, D. (2001). Assessing success on the uniform CPA exam: A logit approach. Journal of Education for Business, September/October, 45-50. https://doi.org/10.1080/08832320109599670

Burton, H., Daugherty, B., Dickins, D., \& Schisler, D. (2014). Will I pass the CPA exam? The relationship between individuals" characteristics and experience, and passing the CPA exam. Retrieved from https://blog.cengage.com/wp-content/uploads/2014/05/Winter-2014.Burton.Daugherty.Dickins.Schisler.Will -I-Pass-The-CPA-Exam.pdf

Campbell, A., Lindsay, D., \& Foote, P. (2000). Does a government/not-for-profit program requirement improve CPA exam pass rates? The Government Accountants Journal, 49(2), 38-44.

Cardona, R., González, K., \& Figueroa, C. (2015). An examination of factors affecting the passing rates of the CPA examination. Retrieved from http://cicia.uprrp.edu/PII/rogelio_cardona_informe_final.pdf

Charron, K., \& Lowe, J. (2009). Becoming a CPA: Evidence from Recent Graduates. The Accounting Educators' Journal, XIX, 143-160.

Cocozza, C. (2005). With CPA exam, perfect makes the practice. Pennsylvania CPA Journal, 76(2), 1-2.

Dunn, W., \& Hall, T. (1984). An empirical analysis of the relationships between CPA examination candidate attributes and candidate performance. The Accounting Review, 59(4), 674-689.

Hahn, W., \& Fairchild, Ch. (2015). Usefulness of the uniform certified public accounting examination for assessment of learning and program quality determination at U.S. institutions of higher learning. Journal of Accounting and Finance, 15(5), 95-108.

Harb, N., \& El-shaarawi, A. (2007). Factors affecting business students' performance: The case of students in United Arab Emirates. The Journal of Education for Business, 82(5), 282-290. https://doi.org/10.3200/JOEB.82.5.282-290

Howell, C., \& Belk, R. (2003). Can the relative difficulties of the CPA and Bar exam explain difference in their passing rates? Retrieved from http://www.newaccountantusa.com/newsFeat/pdf/cpavjdzz.pdf

Howell, C., \& Heshizer, B. (2006) AACSB Accreditation and Success on the Uniform CPA Exam. Journal of Applied Business and Economics, 6(3), 9-17.

Jalagat, R. (2016). Performance in CPA board examination: Benchmarking for opportunities to meet market demands. International Journal of Social Science and Economic Research, 1(9), 1350-1381.

Kukreja, G., \& Al Aali, M. (2013). The determinants of students' performance in introductory accounting courses: Evidence from Kingdom of Bahrain. Journal of Emerging Issues in Economics, Finance and Banking (JEIEFB), 1(3), 183-201.

Lightweis, S. (2014). Bridging the gap between accounting students and the profession: A case study. Higher Education Studies, 4(5), 18-27. https://doi.org/10.5539/hes.v4n5p18

Lindquist, T., \& Smith, G. (2013). Top Schools' Success on the Computerized CPA Exam. The CPA Journal, May, 66-71.

Lindsay, D., Tan, K., \& Campbell, A. (2009). Candidate performance on the business environment and concepts section of the CPA exam. American Journal of Business Education, 2(7), 35-42. 
https://doi.org/10.19030/ajbe.v2i7.4582

Masasi, N. (2012). How personal attribute affect students' performance in undergraduate accounting Course. A case of adult learner in Tanzania. International Journal of Academic Research in Accounting, Finance and Management Sciences, 2(2), 201-2011.

Metinko, T., \& Gray, D. (2010). Decrease in the number of people taking the CPA exam not due to the 150-hour requirement. American J. of Business Education, 3(11), 45-51. https://doi.org/10.19030/ajbe.v3i11.437

Momany, M. (2013). The relationship between professional exam performance and certain demographic characteristics of Jordanian CPA candidates. Global Review of Accounting and Finance, 4(1), 119-132. https://doi.org/10.2139/ssrn.2134406

Morgan, J. (2015). The relationship of CPA exam delay after graduation to institutional CPA exam pass rates. Journal of Finance and Accountancy, 18(January), 1-11.

Morgan, J., Bergin, J., \& Sallee, L. (2008). An investigation of the relationship between AACSB Business School Accreditation and CPA Exam success rates. Journal of Business \& Leadership: Research, Practice, and Teaching, 4(1), 20-32, available at: http://scholars.fhsu.edu/jbl/vol4/iss 1/4

Odia, J., \& Ogiedu, K. (2013). Factors affecting the study of accounting in Nigerian universities. Journal of Educational and Social Research, 3(3), 89-96. https://doi.org/10.5901/jesr.2013.v4n3p89

Perez, C. (2013). Performance of BSA graduates in the CPA licensure examination: Basis of enhancement. LPU-Laguna Journal of Multidisciplinary Research, 4(3), 98-117.

Reilly, F., \& Stettler, H. (1972). Factors influencing success on the CPA examination. Journal of Accounting Research, 10(2), 308-321. https://doi.org/10.2307/2490011

Samsuri, A., Arifin, T., \& Hussin, S. (2016). Perception of undergraduate accounting students towards professional accounting career. International Journal of Academic Research in Accounting, Finance and Management Sciences, 6(3), 78-88. https://doi.org/10.6007/IJARAFMS/v6-i3/2173

Shbaugh, D., \& Thompson, A. (1993). Factors distinguishing exceptional performance on the uniform CPA Exam. J. of Education for Business, 68(6), 334-337. https://doi.org/10.1080/08832323.1993.10117638

Sugahara, S., \& Boland, G. (2014). How accounting students define success, and the factors affecting their success and failure, while studying in the accounting schools of Japan. Procedia - Social and Behavioral Sciences, 141, 64-69. https://doi.org/10.1016/j.sbspro.2014.05.012

Sugahara, S., Hiramatsu, K., \& Boland, G. (2009). The factors influencing accounting school students' career intention to become a certified public accountant in Japan. Emerald Insight - Asian Review of Accounting, 17(1), 5-22. https://doi.org/10.1108/13217340910956487

Suluom, S., \& Masoud, M. (2014). The relationship between undergraduate academic achievement and professional examinations performance. Business Management Review, 17, 14-34

Suyder, A. (2004). Tips on preparing employees for the new CPA exam. J. of Acc., 11-12. Retrieved from https://www.journalofaccountancy.com/issues/2004/mar/tipsonpreparingemployeesforthenewcpaexam.html

Tan, J. (2014). Academic performance, aspirations, attitudes and study habits as determinants of the performance in licensure examination of accountancy graduates. International J. of Education \& Research, 2(12), 61-70.

Tan, J. (2015). Performance in the accountancy licensure examination of the University of Eastern Philippines: A look at curriculum and instruction. Innovative Space of Scientific Research Journals, 11(3), 598-607. https://doi.org/10.21016/IRRC.2014.14NTT032

Titard, P., \& Russell, K. (1989). Factors affecting CPA examination success. Accounting Horizons, 3(3), 53-59.

Trinkle, B., Scheiner, J., Baldwin, A., \& Krull, G. (2016). Gender and other determinants of CPA exam success: A survival analysis. The Accounting Educators' Journal, 16, 101-118.

Whitten, D., \& Brahmassrene, T. (2002). Passing the uniform CPA exam: What factors matter. The CPA Journal, November, 1-2.

\section{Copyrights}

Copyright for this article is retained by the author(s), with first publication rights granted to the journal.

This is an open-access article distributed under the terms and conditions of the Creative Commons Attribution license (http://creativecommons.org/licenses/by/4.0/). 